DOI: 10.32703/2415-7422-2021-11-1-26-37

\title{
Leonid Griffen
}

UDC 62.930.8:71:06-9/13

National Historical and Architectural Museum "Kyiv Fortress"

24a, Hospitalna Street, Kyiv, Ukraine, 01133

E-mail: lagrif@i.ua

https://orcid.org/0000-0002-3020-9636

\section{Nadiia Ryzheva}

V. O. Sukhomlynskyi National University of Mykolaiv

24, Nikolska street, Mykolaiv, Ukraine, 54001

E-mail: ryzheva.nadiya@gmail.com

https://orcid.org/0000-0001-8379-4325

\section{Technology as a socio-historical phenomenon}

Abstract. The article reveals the authors' vision of the essence of the technology as a sociohistorical phenomenon. It is based on the idea that technology is not only a set of technical devices but a segment of the general system - a society - located between a social medium and its natural surroundings in the form of a peculiar social technosphere, which simultaneously separates and connects them. The main objective purpose of the technosphere is to promote the effective rendering of society-generated entropy outwards; it defines the features of the technosphere as a sociohistorical phenomenon. The analogues of such material formations take place also in wildlife (from the spider-web to the beaver dam) but are very few and arise from the implementation of instinctive programs of the species. In a person's consciousness, such programmes are not given by "nature", they are formed on the basis of "desobjectivation" of technical objects available in society. In the process of "desobjectivation" the essence, the "logic of the subject" becomes the achievement of a person and due to his abilities is filled with new meaning. As a result, the technology is a materially ideal phenomenon: on the one hand, it is a set of technical objects and on the other hand - technical thinking of a person, the highest manifestation of which is technical sciences nowadays. Properly technical objects are created by society to meet the individual and social needs of a person. These are primarily consumption items; due to their manmade nature, the question of production means development arises, which over time becomes increasingly important, especially by virtue of their significant impact on social relations (which in time also require certain technical devices for their implementation). The complex of these devices forms the techno sphere of society as a compound integrity. Not only groups of different in application technical objects become the constituent parts of the technosphere, but also 
their conglomerates designed to perform certain functions, which, similar to the biological branch, were called techno enosis; in the latter at the account of a peculiar "competition", the development of these components in particular and the technosphere integrally takes place. However, despite consistency, the technosphere is a subsystem of a society, therefore, there is no perspective of creating certain laws of its development and an appropriate coherent periodization. For this reason, the scientific periodization of the development of technology as such is connected with the purpose of the given research and is defined by it.

Keywords: technology; technosphere; technical thinking; technical devices; technocenosis

\section{Introduction: problem statement.}

At the present stage of human civilization, the development of the general changes in social realities occurs very quickly. One of its most important factors is the rapid development of technology. Its study and successful interpolation will determine the possibility of the scientific forecast of the influence of technology on the course of iconic processes in society for the near future and will allow improving the conditions of scientific prediction of the technology impact on future social processes. The implementation of this task requires the definition of the essence of technology as a social phenomenon. The researchers have studied this question for a while and still, there are many different perspectives. This problem is studied as by Ukrainian (Vynnyk, 2016; Melnyk, 2010; Mykhailovskyi, 2018; Muratova, 2019; Chornomordenko \& Kachak, 2016; Chursinova, 2014), so foreign (McLain, IrvingBell, Wooff, \& Morrison-Love, 2019; Nishimura, Kanoshima, \& Kono, 2019; Kahlau, Schneider, \& Souza-Lima, 2019; Oliveira, 2020; Ushakov, 2017; Jaspers, 2012) researchers. Consider the existence of different points of view on a set of defined issues.

The purpose of the proposed article is to present an original vision of the specified subject. The accents defined by us seem to be the most approximate to understanding the profound realities of technology as a social phenomenon.

The methods of research are chosen on the basis of historical scientific reliability of technical progress, special methods of technology development processes research. The article is based on scientific, theoretically-critical use of the previous research on the history of technology.

\section{Results and discussions.}

The technology is one of the most important social phenomena and as such deserves close attention. The research of technology as a specific phenomenon presupposes the starting of its definition, though there are lots of them nowadays. Basically, four interpretations of this phenomenon essence are defined, in particular: technology as a tool for work, as a system of artificial bodies of activity, as a public material system, as organized by man substance and energy. The analysis of dozens of 
technology definitions indicates the absence of an expanded definition of the term that would cover all the features of the phenomenon. They either do not include all its manifestations (based mainly on the means of production), or do not sufficiently take into consideration its social nature. It is thought that the comprehension of this social phenomenon should begin with the analysis of society as a system (Kahlau, Schneider, \& Souza-Lima, 2019; Nishimura, Kanoshima, \& Kono, 2019).

According to the generalized by us scientific and theoretical ideas, the development of complex systems (in particular, living ones) provides for their constant complication with carrying out entropy to the external environment. The passage of junction points is followed by the transition to a higher structural level of development, the highest of which is society as a specific biological superorganism. In the process of such development, the role of the appearance of specific material formations, which the "living system" places between itself and the environment, is rather important. Thus, in the animal world, gradually complicated individual material objects - a kind of "proto-technology" (from the spider-web to the beaver dam) are observed (Frojde, 1986, p. 17; Rukovskij, 1991, p. 41) and in the public body, they form the technology as a necessary subsystem of the latter.

The creation of the marked objects in wildlife takes place as an external implementation of instinctive programs with the gradual (in the process of evolutionary development) inclusion of their correction elements on the basis of individual experience. In the society whose constituents (separate individuals) do not possess such a "program" from birth, it is formed in the consciousness of the latter as a "desobjectivation" of external objects of a technology previously created by humans. Then these programs, in their turn, are "objectificated" in human activities, in particular by creating new technical objects that society places between itself and the environment. A unique algorithm is formed: "the technology manifests itself as an active capability and power inherent not only to a separate person but to a person as a social creature and, ultimately, to humanity as a whole" (Aliyeva, 2003).

Consequently, the technology constitutes a social subsystem that forms a technosphere between society and the environment. It is formed by society, but from the materials and by the rules of nature, being a natural anthropogenic formation. The technosphere is the realization of people's activities, in particular their thinking, throughout history, and this world is objectificated - realized in the product - thinking of mankind, a distracted thinking in general. And the individual needs to desobjectivate it, take possession of implemented there types of activity (Rozin, 2013). Remaining a "lifeless" subject, the technology "comes to life", being brought into use by the society in accordance with its purpose. As a result, based on its genesis and conditions of functioning, the technology as a social subsystem has two significantly different, but inseparably linked and attributable to each other "images" - ideal and material, and can be understood only in their "duality". 
Technical thinking is no less important and essential constituent of technology than its material embodiment. It, in the same manner as thinking, is a specific feature of a person. As a physiological process it occurs in each individual brain, but in obligatory interaction with other individuals, the "connection" with which is carried out through the re-encoding of "internal" nerve impulses into "external" generally significant signals through the sign systems and vice versa, which makes individual mental cogitative processes a public one. Accordingly, the result of mental processes objectification is the creation of two different types of material formations - carriers of the pointed signals (signs) and technical objects.

Creation of technical objects at any level of technological development requires appropriate knowledge, which can be obtained in different ways: directly in the process of life-activity (practice); on the basis of aloof observation (contemplation); during the purposeful influence on the subject, its study (experiment). Considering the systemacity of the world around us, on the one hand, and the "fragmentation" of knowledge in different "heads" - on the other hand, they should always be conducted to a system the character of which is determined by the level of knowledge. There are three such systems in history: mythology, philosophy, and science. However, only in the latter one two interrelated forms of cognition are clearly defined: experimental with direct research of the object and theoretical - with the study of its simplified model created for this purpose (Gryffen, 2012).

Nowadays, scientific knowledge has taken the dominant position and covers almost all reality. The system of sciences, the constitution of which is defined differently, was formed. In the most "objectivistic" system (according to "the forms of movement") sciences are divided into natural, with appropriate subdivisions, and social. There is no place for technical sciences in such system. However, often the division of sciences is made according to their purpose: the study of society itself and its habitat. Then the existence of technical sciences, the object of which is the technosphere, which divides (and connects) the natural environment and society as a specific phenomenon of the real world with its features, is natural.

Belonging to that kind of sciences system, the technical sciences still significantly differ from others relative to the specifics of its objective existence (its "manmade" nature) and their own purposes. A Nobel prize holder, a prominent American scientist Herbert Simon emphasized that if the main purpose of natural sciences is perception (analysis prevails), so for the technical sciences an ultimate purpose is to create a "second nature" (synthesis dominates) (Sajmon, 2004) In an experimental research, the main thing is not to obtain knowledge, but to improve the object. As for theoretical research, since in each case the ultimate goal is to create a class of technical devices, a kind of simplified model turns out to be a specific real device of this class.

The creation of technical devices is carried out by society to meet the needs of a person, and therefore their character and "nomenclature" are largely defined by these needs (Maslow, 1954). Among a significant number of systems emphasizing different human needs the so-called "Maslow's hierarchy of needs" is the most wide-spread. 
However, it does not take into account the fact that the carrier of needs - the individual - is simultaneously an element of higher integrity (society). It is he who, by virtue of his complexity and his own prehistory, is an integral system. It follows that two interconnected systems of needs are peculiar for a person. Thus, the composition and functions of the technical system should take into account both individual needs of a person (in objects of assimilation, creating comfortable conditions, providing constant physical and mental job), and social needs (in society as such, communication, selfesteem).

In primitive society, a complex of things that provided material interaction of the tribe community with the environment, was concentrated in the dwelling of that time (including the latter) (Tolochko \& Stanko, 1997). With respect to the unity of production and consumption, the labour sharing (except sex and age distinction) did not exist as well as the differentiation of technical objects types. At the same time, the dwelling became an environment which confronted the external world, it was the place of each individual person formation - both in desobjectivation of manmade objects and in meeting social needs. Therefore, in this case, the technical system was of a syncretic character.

The technical objects, usually called consumption items, first of all, serve to meet the individual needs of people. Regarding assimilation problems, the consumption items mainly play a supporting role. And the needs of comfortable conditions are almost fully provided with their help. The appointed needs have a wide assortment from clothing to sports devices. In fact, these very items are the things a person really needs.

However, the "man-made" nature of the necessary consumption items naturally causes the appearance of other technical devices, which are not directly aimed at meeting human needs, but provide the possibility of their creation - the production tools (or, more broadly, means of production). One of the first to deal with the problems of aesthetics of technical objects and industrial design was Franz Reuleaux (1829-1905 biennium), an outstanding German mechanic engineer, lecturer of the Royal Technical School in Berlin (nowadays, Berlin Technical University). He was called "Poet of Technology" and believed that with the help of technical devices in general, or tools in particular, we make "the internal processes of the material world to act and work for our purpose" (Ryolo, 1885, p. 1). They provide the creation of other types of technologies, in particular the means of production, for further technological progress. The importance of this type of technology involves their significant influence on industrial relations, namely, the social system, creating working conditions. In the process of society and technology development, this type of technology progresses at the fastest pace and becomes the most diverse. It consists of numerous classes and subclasses, significantly expanding social opportunities in interaction with the environment (McLain, Irving-Bell, Wooff, \& Morrison-Love, 2019). Thus, it should be logical to conclude that the means of work are not only the criterion of the human 
labour power development but also the indicator of social relations in which labour is carried out.

However, the society in interaction with the environment faces the need to act in the form of integrity, which with its quantitative growth and spread also involves the use of certain technical means (in order to provide integrity). The means of communication supposed to provide material (substantial and energetic) (transport) and informational (linking) streams serve as unifying, integrated objects. They fulfill this role both in reference to the elements of society - individuals and social groups, and to their production activities. The latter comprises communication means as belonging to the means of production.

The increasing number of social entities leads to the intensification of various kinds of contacts between them. The growth and complicacy of each entity are also accompanied by structural changes. They are primarily connected with the distribution of labour and the distinguishing of separate production social groups with different interests. In both cases, the appropriate types of technical devices (separate) are needed, which, above all, include weapons and military technology in general. Another type of technical devices of this kind is articles of luxury. Such articles can be used both as special technical devices and the objects of other technology types, which obtain a high-status character.

Accordingly, the technology is a system with a complex structure, which is due to its transformation into a dynamic developing system. In this context, the technosphere is compared to the biosphere. It stands to reason that there is a significant difference between the elements of these dynamic systems - the biological personality and the technical device (product). First of all, it is the difference between the living and the lifeless. This specific element includes differences both in functioning (regarding entropy) and in structure (heterogeneity of materials in the first case, and homogeneity - in the second one). However, there is something in common between them, as complex formations require a certain "previous plan" for their implementation. Although there are significant differences in this case too (Libberta, 1982, p. 18).

The biological personality is self-created in accordance with the program laid in its genotype, which is connected with each cell of the organism. Its "construction" is a process that in ontogenesis repeats phylogenetic development - since a biological person, regardless of the development level in ontogenesis, should successfully function in the environment as a separate organism at each stage. The technical device is created by a society from ready-made components, and only in a programmed form it starts to function by itself. But it also needs some kind of genotype - external in regard to this device. Today, such a "genotype" is a document (sometimes called a passport), without changes in which no "phenotypic" transformations in the device is possible. Still, in both cases, the new peculiarities of "organisms" arise in the form of random mutations in the genotype, which are fixed in with respect to natural selection or social practice. 
Another important similarity of technical and biological is that in both cases a separate "organism" can only function in a particular conglomerate (Malaspina, 2019). This refers not only to the biosphere or the technosphere as a whole but also to some local unities, which are called "biocenosis" in relation to living organisms. Technical devices, by analogy, received such name as "technocenosis". Cenosis is a kind of system that differs from the system properly in that its whole structure is influenced much more by the properties of separate components which are already included in it. These communities of any kind have a common - as distinct from Gaussian - nature of the elements distribution. It is in the composition of cenosis that specific technical devices perform functions in the technosphere, and therefore largely determine the dynamics of the latter.

It stands to reason that the development of technology in general and in its structural and functioning units, as well as any material objects, is directed by certain patterns. Therefore, the researchers seek to find the "general laws" of this development. In our opinion, such question setting is as scientifically incorrect as attempts to find the "general laws" of physics or biology. Regarding the technology, the attempt to use the so-called "laws" of Hegelian dialectic cannot be recognized as legitimate. These "laws" are designed for an ideal single object that does not arise, does not disappear, and does not come into interaction with anything. This fundamentally distinguishes an ideal single object from real objects. Valid "laws of technology" should concern its real objects, even if they have different levels of generalization and idealization.

Since the development of technology is a historical process, there is a problem of its periodization. The corresponding numerous periodizations are reduced to two basic principles. As for the first, the periodization of the development of technology as a social phenomenon should coincide with the periodization of society development; according to the second, the technology in its development is self-sufficient, subordinate to its own laws and not only independent of the development of society but dramatically affects it. Both principles reflect the significant features of technology and have the right to exist. However, in reality, the development of technology that complies with two different types of consistent patterns, cannot be determined by any of them. Therefore, the periodization of its development can be the only relative, depending on the purpose of the research.

The main direction of the general development of technology is the gradual transference of partial technical functions of a person to technical devices. Initially, it concerned the tool that interacted with the subject of work and changed it directly; subsequently - types of energy spent by a human being on this interaction (muscle strength, then - the energy of animals, and then - the forces of nature), and finally control and management of these processes. Today, despite the importance of all appointed aspects, the latter gained special attention. It is associated with a significant increase of productivity, and what is the most important, a gradual more and more complete transference of "alive" workers' functions to the technical systems. 
Eventually, the time when only the purposefulness and general control will be kept by a person and everything else will be performed by technical systems will come.

\section{Conclusions.}

One of the most important social phenomena - technology, comprises a created by mankind in relation to the environment a special sphere that separates them and simultaneously connects with each other. Materially specified technosphere consists of a system of technical devices designed both to meet the needs of separate individuals and society as a whole. However, the set of technical devices inherently is not yet a technology, because only the direct efforts of people "restores it to life" and makes it effective. The development of technology is of spontaneous character and is determined by the momentum of socio-historical evolution, not intrinsically but through interaction with the relevant structural and functional changes of human society.

\section{Funding.}

This research received no external funding.

\section{Conflicts of Interest.}

The author declare no conflict of interest.

\section{References}

Aliyeva, O. G.(2003). Fenomen texniky v suchasnij kulturi [The phenomenon of technology in modern culture]. Multyversum. Filosofskyi almanakh Multiversum. Philosophical almanac, (37), 252-261 [in Ukrainian].

Chornomordenko, I. V., \& Kachak, N. V. (2016). Teoretyko-metodolohichni zasady stanovlennia, rozvytku ta transformatsii filosofii tekhniky v epokhu hlobalizatsii [Theoretical and methodological basis of genesis, development and transformation of philosophy of technology in the era of globalization]. Hileia. Filosofski nauky - Gileya. Philosophical sciences, 105(2), 225-229. Retrieved from http://gileya.org/download.php?id=127 [in Ukrainian].

Chursinova, O. (2014). Sotsialno-antropolohichni aspekty suchasnoi ukrainskoi filosofii tekhniky [Socio-anthropological aspects of modern Ukrainian philosophy of technology]. Bulletin of the National University "Lviv Polytechnic" - Bulletin of the National University "Lviv Polytechnic", (780), 53-57. Retrieved from http://ena.lp.edu.ua:8080/bitstream/ntb/26209/1/10-53-57.pdf [in Ukrainian].

Sajmon, G. (2004). Nauki ob iskusstvennom [Sciences of the artificial]. Moscow: Editorial URSS [in Russian]. 
Gryffen, L. A.(2012). Obshhestvennye formy znanyya [Social forms of knowledge]. Nauka ta Naukoznavstvo - Science and Science of Science, (2), 135-142 [in Ukrainian].

Frojde, M. (1986). Zhivotnye stroyat [The animals are building]. Moscow: Mir [in Russian].

Kahlau, C., Schneider, A, \& Souza-Lima, J. (2019). the social technology as an alternative to development: questions about Science. Technology and Society, 15(36), 190-213. https://doi.org/10.3895/rts.v15n36.8128

Libberta, Eh. (Eds). (1982) Osnovy obshchej biologii [Fundamentals of General Biology]. Moscow: Mir [in Russian].

Malaspina, S. (2019). Pure information: about infinity and human nature in a technical object. Culture, Theory and Criticism, 60(3-4), 205-222. https://doi.org/10.1080/14735784.2019.1680300

Maslow, A. H. (1954). Motivation and Personality. New York: Harper \& Row Publishers.

McLain, M., Irving-Bell, D., Wooff, D., \& Morrison-Love, D. (2019) How technology makes us human: cultural historical roots for design and technology education. Curriculum Journal, 30(4), 464-483. https://doi.org/10.1080/09585176.2019.1649163

Melnyk, V. P. (2010). Filosofiia. Nauka. Tekhnika: Metodoloho-svitohliadnyi analiz[Philosophy. Science. Technology: methodological and ideological analysis]. Lviv: Ivan Franko National University of Lviv [in Ukrainian].

Muratova, I. A. (2019). Sotsialna otsinka tekhniky v konteksti sotsialno-filosofskoho doslidzhennia tekhnolohii [Social evaluation of technology in the context of socio-philosophical research of technology]. Hileia. Filosofski Nauky - Gileya. Philosophical Sciences, 149(10(2)), 100-106. Retrieved from http://gileya.org/download.php?id=210 [in Ukrainian].

Mykhailovskyi, A. (2018). Antropolohichnyi vymir tekhniky: filosofski aspekty [Anthropological dimension of technology: philosophical aspects]. Visnyk Lvivskoho Universytetu. Filosofsko-Politolohichni Studii - Visnyk of the Lviv University Philosophical Political Studies, (16), 45-50. Retrieved from http://fpsvisnyk.Inu.lviv.ua/archive/16_2018/8.pdf [in Ukrainian].

Nishimura, H., Kanoshima, E. H., \& Kono, K. (2019). Advancement in science and technology and human societies. Science of Societal Safety: Living at Times of Risks and Disasters, 2, 15-26. https://doi.org/10.1007/978-981-13-2775-9_2

Oliveira, L. V. (2020). Science-technology-society: from the historical-ontological foundations to some analytical principles. Technology and society, 16(42), 1-21. https://doi.org/10.3895/rts.v16n42.10324 [in Portuguese].

Rozin, V. M. (2013). Filosofiya tekhniki: istoriya $i$ sovremennost [Philosophy of technology: history and modernity]. Moscow: Directmedia [in Russian].

Rukovskij, N. N. (1991). Ubezhishcha chetveronogikh [Four-footed shelters]. Moscow: Agropromizdat [in Russian]. 
Ryolo, F. (1885). Tehnika i ee svyaz s zadachey kulturyi [Technology and its connection with the task of culture]. Sankt Peterburg: Ministry of Railways [in Russian].

Tolochko, P. P., \& Stanko, V. N. (Eds). (1997). Davnya istoriya Ukrayiny [Ancient history of Ukraine] (Vol. 1-8). Kiev: Naukova dumka [in Ukrainian].

Vynnyk, U. (2016). Filosofskyi zmist perspektyvy humanizatsii tekhniky [Philosophical content of the technology humanization perspective]. Visnyk Prykarpatskoho Universytetu. Filosofski i Psykholohichni Nauky-Bulletin of the Precarpathian University. Philosophical and Psychological Sciences, (20), 135142 [in Ukrainian].

Ushakov, E. V. (2017). Filosofiya tekhniki i tekhnologii [Philosophy of technology and technology]. Moscow: Izdatelstvo Yurayt [in Russian].

Jaspers, K. (2012). Filosofiya [Philosophy]. Moscow: Kanon [in Ukrainian].

\section{Леонід Гріффен}

Національний історико-архітектурний музей “Київська фортеця”, Україна

\section{Надія Рижева}

Миколаївський національний університет імені В. О. Сухомлинського, Україна

\section{Техніка, як соціально-історичне явище}

Анотація. У статті презентовані уявлення авторів про сутність техніки, як соціально-історичного явища. В його основі лежить погляд на техніку не просто як на сукупність технічних пристроїв, але як на підсистему загальної системи - суспільства, що розташована між соиіумом $i$ його природним оточенням у вигляді своєрідної суспільної техносфери, що їх одночасно розмежсову й об'єднує. Основне об 'єктивне призначення техносфери - сприяти ефективному винесенню генерованої суспільством ентропії назовні; воно визначає характеристики техносфери як сочіально-історичного явища. Аналоги такого роду матеріальних утворень мають місие й у тваринному світі (від павутиння до бобрової греблі), однак $є$ поодинокими й виникають унаслідок реалізаиії інстинктивних програм особин. У свідомості людини такі програми не закладаються "природою”, вони формуються на основі "розпредмечення" наявних у суспільстві технічних об'єктів. У процесі “розпредмечення" сутність, “логіка предмета" стають досягненням людини $i$ завдяки ї здібностям наповнюються новим змістом. У такий спосіб, техніка становить явище матеріально-ідеальне: з одного боку ие сукупність технічних об 'єктів, а з іншого - технічне мислення людини, вищим проявом якого сьогодні є технічні науки. Власне, технічні об'єкти створюються суспільством для задоволення індивідуальних $i$ суспільних потреб людини. Це, перш за все, предмети споживання; $y$ зв'язку з їх рукотворністю постає питання розвитку засобів 
виробництва, щуо з часом набуває все більшого значення, особливо завдяки їхньому істотному впливу на всі суспільні структури (які згодом для реалізації конкретних завдань також вимагають певних технічних пристроїв). Комплекс цчих пристроїв формує техносферу суспільства як складну иілісність. Складниками техносфери стають не лише групи різних за призначенням технічних об'єктів, але й їхні конгломерати, призначені для виконання певних функцій, які, аналогічно до біологічної галузі, отримали назву техноченозів; в останніх за рахунок своєрідної “конкуренції” відбувається розвиток указаних складників зокрема $i$ техносфери в цілому. Однак, попри системність, техносфера є підсистемою суспільства, отже, годі сподіватись на віднайдення окремих законів ї̈ розвитку і створення відповідної ияілісної періодизації. Тому наукова періодизація розвитку власне техніки пов'язана з метою конкретного дослідження і визначена нею.

Ключові слова: техніка; техносфера; технічне мислення; технічні пристрої; техноценози

\section{Леонид Гриффен}

Национальный историко-архитектурный музей “Киевская крепость”, Украина

\section{Надежда Рыжева}

Николаевский национальный университет имени В. А. Сухомлинского, Украина

\section{Техника, как социально-историческое явление}

Аннотация. В статье изложень представления авторов о сущуности техники, как сочиильно-исторического явления. В его основе лежит взгляд на технику не как на совокупность технических устройств, а как на подсистему общей системь - общества. Расположенная в виде своеобразной общественной техносферы, между сочиумом и его природным окружением, она одновременно разграничивает и объединяет их. Основное объективное назначение техносферь - способствовать эффективному вынесению генерируемой обществом энтропии наружу; оно определяет характеристики техносферы как сочиально-исторического явления. Аналоги такого рода материальных образований имеют место и в жсиотном мире (от паутины до бобровой плотинь), однако они единичные и возникают вследствие реализачии инстинктивных программ особей. В сознании человека такие программы не закладываются “природой”, они формируются на основе "распредмечивания” имеющихся в обществе технических объектов. В прочессе "распредмечивания” сущность, “логика предмета” становятся достижением человека и, благодаря его способностям, наполняются новым содержанием. Таким образом, техника представляет явление материально-идеальное: $c$ одной сторонь, это совокупность технических объектов, а с другой - техническое мыпление 
человека, высшим проявлением которого сегодня являются технические науки. Собственно, технические объекты создаются обществом для удовлетворения индивидуальных и общественных потребностей человека. Это, прежде всего, предметь потребления; в связи с их рукотворностью возникает вопрос совершенствования орудий производства, что со временем приобретает все большее значение, особенно благодаря их сущуественному воздействию на все структуры общества (которые для реализации конкретных задач также требуют определённых технических устройств). Комплекс этих устройств формирует техносферу общества как сложную цуелостность. Составляюшими техносферы становятся не только группь различных по назначению технических объектов, но и их конгломераты, предназначенные для выполнения определенных функций. По аналогии с биологической отраслью они получили название техноценозов, в последних за счет своеобразной “конкуренции” происходит развитие указанных составляющих в частности и техносферы в цуелом. Однако, несмотря на системность, техносфера является подсистемой общества, следовательно, не стоит надеяться на обнаружение отдельных законов ее развития и создание соответствующей изелостной периодизации. Поэтому научная периодизачия развития собственно техники связана с целью конкретного исследования и определена ею.

Ключевые слова: техника; техносфера; техническое мыиление; технические устройства; техноченоз

Received 22.10.2020

Received in revised form 03.02.2021

Accepted 05.03.2021 